Review

\title{
Addition and Cycloaddition Reactions of Phosphinyl- and Phosphonyl-2H-Azirines, Nitrosoalkenes and Azoalkenes
}

\section{Américo Lemos}

CIQA, Faculdade de Ciências e Tecnologia, Universidade do Algarve, Campus de Gambelas, 8005-137 Faro, Portugal; E-Mail: alemos@ualg.pt

Received: 25 August 2009; in revised form: 23 September 2009 / Accepted: 12 October 2009 / Published: 13 October 2009

\begin{abstract}
An overview of the use of $2 H$-azirines, conjugated nitrosoalkenes and conjugated azoalkenes bearing phosphorus substituents in addition and cycloaddition reactions is presented, focused on strategies for the synthesis of aminophosphonate and aminophosphine oxide derivatives.
\end{abstract}

Keywords: $2 H$-azirine; nitrosoalkene; azoalkene; phosphonyl; phosphinyl

\section{Introduction}

Over recent years we and others have investigated the use of $2 \mathrm{H}$-azirines, conjugated nitrosoalkenes and conjugated azoalkenes in nucleophilic addition and cycloaddition reactions. The structures I, II and III of these three classes are outlined in Figure 1.

Figure 1. Name, structure and numbering of compounds.

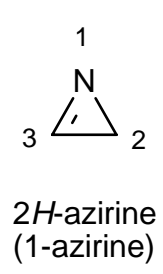

I

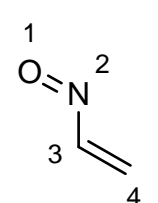

nitrosoalkene

II

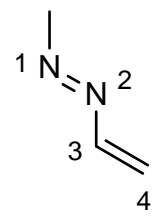

azoalkene

(1,2-diaza-1,3-butadiene)

III 
A common feature of all three structures is that they possess a highly electrophilic carbon centre (C-3 in 2H-azirines, C-4 in conjugated nitroso- and azo-alkenes) that allows nucleophilic addition reactions to proceed very readily. In reactions of nucleophiles with $2 H$-azirines this often leads eventually to opening of the three membered ring. The electrophilic character of these structures also allows cycloaddition reactions, particularly those with nucleophilic olefins, to take place under very mild conditions. Such reactions have provided routes to a variety of novel heterocyclic structures which have proved to be very useful targets, not only due to their eventual biological and pharmacological properties, but especially to their wide and versatile use as synthetic intermediates or useful building blocks for the synthesis of amino acids, pyrroles, proline, indoles, pyrazines, and azasugars derivatives, amongst many other compounds [1-11].

Aminophosphonic and aminophosphinic acid derivatives can be considered as isosteres or surrogates of aminocarboxylic acids and they regulate various important biological functions [12-16]. In this context it is not surprising that organic chemists have been attracted to them and have paid particular attention to the synthesis of these types of compounds. The aim of this review is to illustrate the particular use of above reaction types of $2 \mathrm{H}$-azirines, nitrosoalkenes and azoalkenes bearing phosphinyl or phosphonyl substituents, for the construction of alkyl $\alpha$ - and $\beta$-aminophosphonates and aminoalkylphosphine oxides.

\section{2H-Azirines}

$2 \mathrm{H}$-Azirines are strained and activated imines. Their high reactivity makes them very useful synthetic intermediates for the synthesis of aziridines, amino acids, indoles, pyrazines, and other biologically active compounds through cycloaddition and nucleophilic addition reactions $[3,5,6,8,9,17]$.

\subsection{Synthesis}

Despite all these potential applications, $2 \mathrm{H}$-azirines bearing phosphorus substituents have received comparatively little attention. Photocyclization of vinyl azides [18], reaction of phosphites with $\beta$-nitrostyrenes [19] and carbene addition to aromatic nitriles [20,21] constituted the earlier examples of $2 \mathrm{H}$-azirines with a phosphinyl or phosphonyl functional group. Afterwards, a diverse methodology based on Swern oxidation of chiral aziridines 1 and 2, produced regioisomeric mixtures of azirinyl phosphonates 3-5 (Scheme 1) [22,23].

Thermolysis of vinyl azide 6 [24] allowed the isolation of diphenylphosphinyl $2 H$-azirine 7 in good yield (Scheme 2), but this strategy was not suitable for the preparation of enantiopure azirines.

The asymmetric synthesis of $2 \mathrm{H}$-azirines bearing phosphinyl [24] and phosphonyl [25] substituents was disclosed by alkaloid mediated Neber reactions of $\beta$-keto tosyloximes. Similarly, the use of chiral polymer-supported bases [26] led to $2 \mathrm{H}$-azirines 9 regioselectively and in high yields (Scheme 3 ).

Another approach based on the treatment of phosphorylated allenes $\mathbf{1 1}$ with sodium azide was the basis of a convenient methodology for the synthesis of 3-vinyl- and 3-dihydroisoxazolyl-2 $\mathrm{H}$-azirines 13 and 16 (Scheme 4) [27,28]. 
Scheme 1. Synthesis of $2 H$-azirines by Swern oxidation.

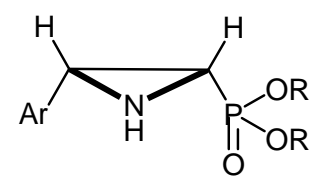

1 a-c

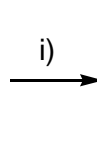<smiles>[R]OP([R])(=O)C1=N[C@@H]1[AlH2]</smiles>

$(R)-3 \mathbf{a ~ R}=\mathrm{Et} ; \quad \mathrm{Ar}=\mathrm{Ph}$ b $\mathrm{R}=\mathrm{Me} ; \mathrm{Ar}=4-\mathrm{MeOPh}(68 \%)$ c $\mathrm{R}=\mathrm{Me} ; \mathrm{Ar}=\mathrm{Ph}$<smiles>[R]OP([R])(=O)[C@]1([2H])N=C1[Al]</smiles>

(S) $-\mathbf{4} \mathbf{a} \mathrm{R}=\mathrm{Et} ; \quad \mathrm{Ar}=\mathrm{Ph}$ b $\mathrm{R}=\mathrm{Me} ; \mathrm{Ar}=4-\mathrm{MeOPh}$<smiles>CCOP(=O)(OCC)C1CC(c2ccccc2)N1</smiles>

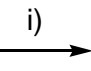

2
(R)- $\mathbf{3}$ a) (40\%)<smiles>CCOP(=O)(OCC)[C@H]1N=C1c1ccccc1</smiles>

(R)- 5 (49\%)

i) DMSO, $\left(\mathrm{COCl}_{2}\right)$; then $\mathrm{Et}_{3} \mathrm{~N}$; $-78^{\circ} \mathrm{C}$ to r.t.

Scheme 2. Thermolysis of vinyl azide $\mathbf{6}$.

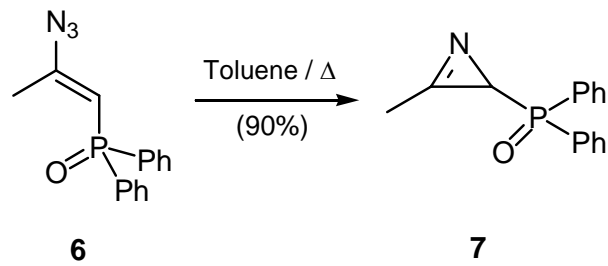

Scheme 3. $2 H$-Azirines by Neber reactions of $\beta$-keto tosyloximes.<smiles>[R]C(CP([R])([R])=O)=N[O-]</smiles>

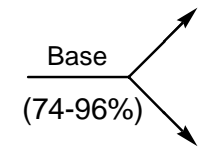

8<smiles>[R]C1=NC1P(=O)(OCC)OCC</smiles>

4a, $9 \mathbf{a} \mathrm{R}^{1}=\mathrm{Me}$ 9b $\mathrm{R}^{1}=\mathrm{Et}$<smiles>[R]C1=N[C@@H]1P(=O)(c1ccccc1)c1ccccc1</smiles>

10a $\mathrm{R}^{1}=\mathrm{Me}$ b $\mathrm{R}^{1}=\mathrm{Et}$

Base $=$ Quinidine; Sparteine; Hydroquinidine;

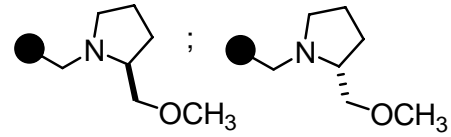


Scheme 4. Synthesis of 3-vinyl- and 3-dihydroisoxazolyl-2H-azirines.<smiles>[R]C(=C=C([R])P(=O)(OCC)OCC)CCl</smiles>

11
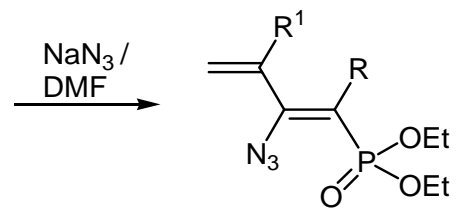

12

$\mathrm{PhCCl}=\mathrm{NOH} 14$ $\mathrm{Et}_{3} \mathrm{~N}$

$\mathrm{Et}_{2} \mathrm{O}$ $\left(\mathrm{R}^{1}=\mathrm{H}\right)$

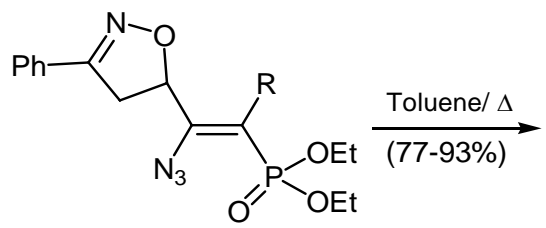

15

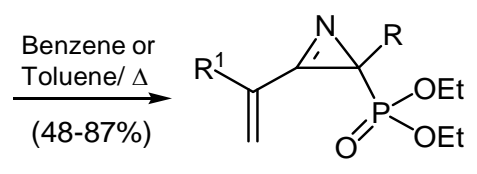

$13 \mathbf{R}^{1}=\mathrm{H} ; \mathrm{Me}$

$\mathbf{R}=\mathrm{H} ; \mathrm{Bu} ; \mathrm{Pen} ; \mathrm{Pr} ; \mathrm{Ph} ; \mathrm{CH}_{2} \mathrm{OH}$

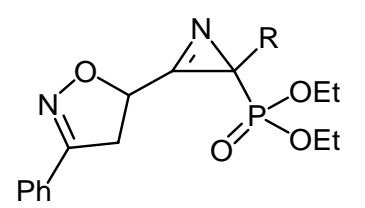

$16 \mathbf{R}=\mathrm{Pr} ; \mathrm{Bu} ; \mathrm{Ph}, \mathrm{CH}_{2} \mathrm{OH}$

\subsection{Addition reactions}

One of the earliest reported reactions of $2 \mathrm{H}$-azirines bearing phosphorus substituents was hydride addition [24,25]. The treatment of azirines 9, 10 with sodium borohydride in ethanol produced cisaziridines exclusively (Scheme 5). The stereochemical assignment was based on the large coupling constant observed for the ring protons and further established by the transformation into enantiopure $c i s-N$-( $p$-toluenesulfinyl)-aziridines by treatment with (-)-(S)-menthyl $p$-toluenesulfinate [24].

Scheme 5. Hydride addition to $2 H$-azirines 9 and $\mathbf{1 0}$.<smiles>[R]C1NC1P(=O)([18OH])OC</smiles><smiles>[R]C1NC1P(=O)(c1ccccc1)c1ccccc1</smiles>

10 a,b
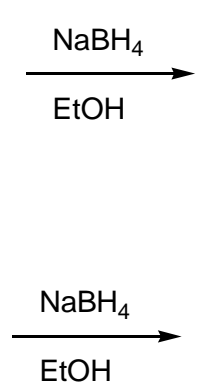

$\mathrm{EtOH}$<smiles>[R]C1NC1P(=O)(OCC)OCC</smiles>

$\begin{aligned} 17 \text { a } R & =\operatorname{Me}(81 \%) \\ \text { b } R & =E t(82 \%)\end{aligned}$<smiles>[Z]C1NC1P(=O)(c1ccccc1)c1ccccc1</smiles>

18 a $R=\operatorname{Me}(80 \%)$ b $\mathrm{R}=\mathrm{Et}(84 \%)$

For the synthesis of $\beta$-amino-phosphine oxide and -phosphonate derivatives 22 from tosyloximes 19, a similar addition of hydride takes place with 3-fluoroalkyl- $2 \mathrm{H}$-azirines $\mathbf{2 0}$-postulated as plausible intermediates - producing regioselectively cis-aziridines $\mathbf{2 1}$ which then lead to compounds $\mathbf{2 2}$ by ring opening [29] (Scheme 6). 
Scheme 6. $\beta$-Amino-phosphine oxides and -phosphonates 22 from tosyloximes 19.<smiles>[R]C1NC1P([R])(=O)CC</smiles>

20<smiles>[R]C(CP([R])([R])=O)=NO[As]</smiles>

19

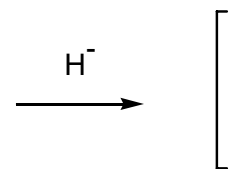<smiles>[R]C1NC1P([R])([R])=O</smiles>

21<smiles>[R]P([R])(=O)CC(N)[18OH]</smiles>

$$
\begin{aligned}
& 22 \mathrm{a} \mathrm{R}_{\mathrm{F}}=\mathrm{CF}_{3} ; \mathrm{R}=\mathrm{Ph} \quad(74 \%) \\
& \text { b } \mathrm{R}_{\mathrm{F}}=\mathrm{CF}_{3} ; \mathrm{R}=\mathrm{OEt}(72 \%)
\end{aligned}
$$$$
\text { c } \mathrm{R}_{\mathrm{F}}=\mathrm{C}_{2} \mathrm{~F}_{5} ; \mathrm{R}=\mathrm{OEt}(45 \%)
$$

Nitrogen heterocycles, in the presence or absence of base, add regioselectively to the azirine nucleus following the general pattern - the attack being from the less hindered face of the azirine yielding functionalized aziridines [29,30] (Schemes 7 and 8).

Scheme 7. Addition of nitrogen heterocycles to $2 H$-azirines 23.

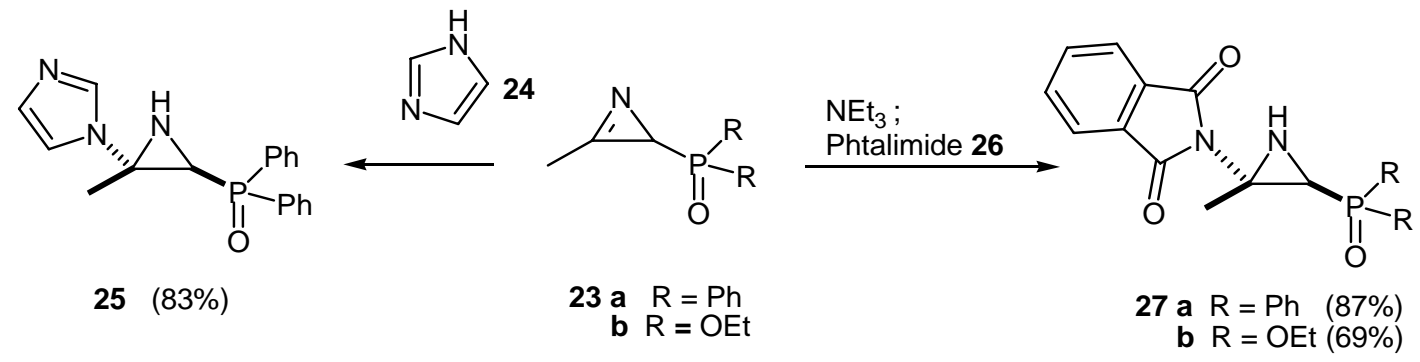

Scheme 8. Imidazole mediated generation of $2 H$-azirine 20a and nucleophilic addition.<smiles>O=P(C/C(=N/O)O[Na])(c1ccccc1)C(F)(F)F</smiles>

$19 \mathrm{a}$
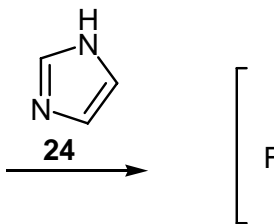<smiles>O=P1(c2ccccc2)CC(C(F)(F)F)C1C1CC1</smiles>

$20 a$
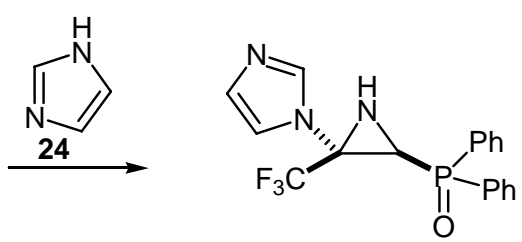

$28(45 \%)$

Oxygen [30] (Scheme 9) and sulfur [29] (Scheme 10) nucleophiles also add in a similar and regioselective mode, to $2 \mathrm{H}$-azirines bearing phosphorus substituents. In the case of the reaction with benzenethiol, if a methyl group is present in the ring of the resulting aziridines, subsequent ring opening reaction leads to $a$-aminophospine oxide and -phosphonates $\mathbf{3 3}$. 
Scheme 9. Methanol addition to $2 H$-azirines 20.<smiles>[R7]C(=NO[As])C([R7])P([R])([R])=O</smiles>

19 a-c $R^{1}=H$ 19d $R^{1}=\mathrm{Me}$

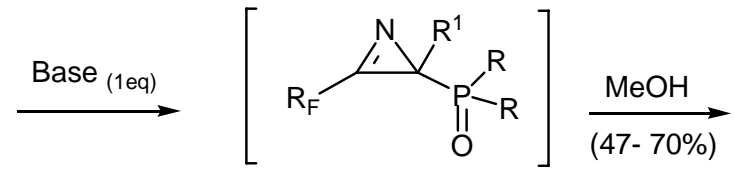

20a-d

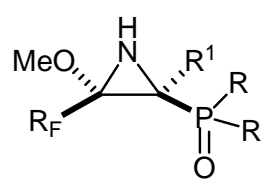

$29 \mathrm{R}_{\mathrm{F}}=\mathrm{CF}_{3} ; \mathrm{CHF}_{2} ; \mathrm{C}_{7} \mathrm{~F}_{15}$ $\mathrm{R}=\mathrm{Ph} ; \mathrm{OEt}$ $\mathrm{R}^{1}=\mathrm{H} ; \mathrm{Me}$

Scheme 10. Benzenethiol addition to $2 H$-azirines 23 and 29 .<smiles>[R]C1NC1P(C)(=O)F</smiles>

23 a,b

$29 \mathrm{R}=\mathrm{R}^{1}=\mathrm{Ph}$ $\mathrm{PhSH} 30$
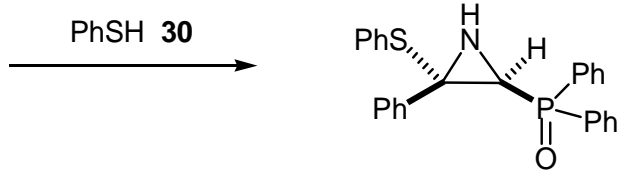

$31(58 \%)$

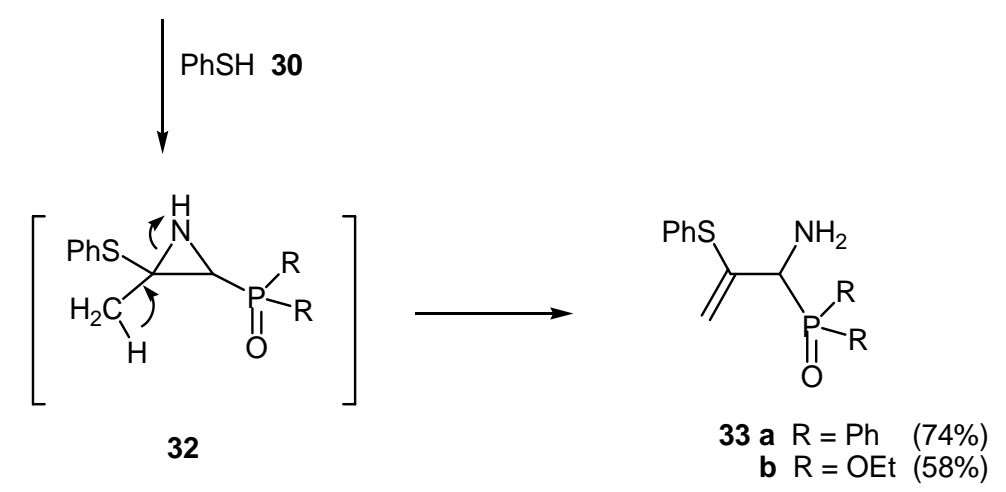

The addition of Grignard reagents to 2-phosphinyl- and 2-phosphonyl-2H-azirines is less simple. Early reports with 2,3-diphenyl-2H-azirine revealed that the reaction followed the general pattern of addition of nucleophiles, i.e., the obtained aziridines arise from the attack at the less hindered face of the azirine [31]. These findings are in clear contrast with those obtained with alkyl $2 \mathrm{H}$-azirine-2carboxylates, in which the syn addition -to the more hindered face- is preferred (Scheme 11) [32,33]. These facts have been ascribed to a prechelating effect of the Grignard reagents with carboxylate substituents.

Scheme 11. Addition of Grignard reagents to $2 H$-azirine-2-carboxylates.

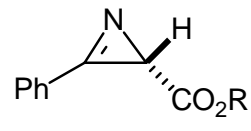

34

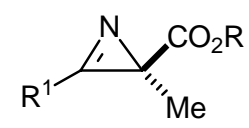

37

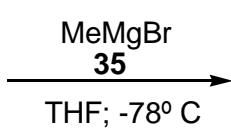

$\mathrm{R}^{2} \mathrm{MgBr}$

35,38

$(30-93 \%)$ (67- >94\%de)

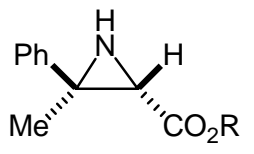

36a $R=\operatorname{Me}(60-65 \%)$

b $\mathrm{R}=\mathrm{CMe}_{3}(75 \%)$

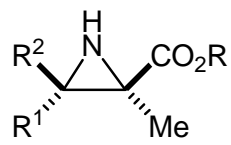

$39 \mathrm{R}=\mathrm{Me} ; \mathrm{CM}_{3} ; \mathrm{R}^{1}=\mathrm{Ph} ; n-\mathrm{Pr}$ $\mathrm{R}^{2}=\mathrm{Me} ; \mathrm{Et} ; n-\mathrm{Bu} ; i-\mathrm{Pr}$ 
When the carboxylate group was replaced by a phosphoryl group, the reverse preference was observed, i.e., an exclusive attack at the least hindered side was encountered [30] (Table 1).

Table 1. Addition of Grignard reagents.

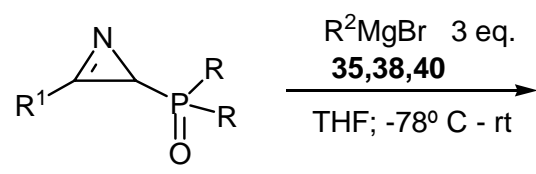

23 a,b; 29

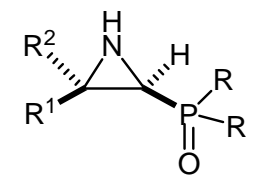

41

\begin{tabular}{ccccc}
\hline compound & $\mathrm{R}$ & $\mathrm{R}^{1}$ & $\mathrm{R}^{2}$ & yield (\%) \\
\hline $\mathbf{4 1 a}$ & OEt & $\mathrm{Me}$ & $\mathrm{Et}$ & 60 \\
$\mathbf{4 1 b}$ & OEt & $\mathrm{Me}$ & $\mathrm{Bz}$ & 66 \\
$\mathbf{4 1 c}$ & OEt & $\mathrm{Ph}$ & Allyl & 87 \\
$\mathbf{4 1 d}$ & $\mathrm{Ph}$ & $\mathrm{Me}$ & $\mathrm{Et}$ & 57 \\
$\mathbf{4 1 e}$ & $\mathrm{Ph}$ & $\mathrm{Me}$ & Allyl & 68 \\
$\mathbf{4 1 f}$ & $\mathrm{Ph}$ & $\mathrm{Me}$ & 2-ethyl-[1,3]-dioxolanyl & 65 \\
$\mathbf{4 1 g}$ & $\mathrm{Ph}$ & $\mathrm{Ph}$ & Allyl & 63 \\
\hline
\end{tabular}

This behaviour has been ascribed to the high exocyclic dihedral angle of the saturated carbon and to the presence of a bulky tetrahedral phosphorus group. But if a chelating substituent, such as alkylfluoromethyl or perfluoroalkylmethyl is present beside the phosphorus group, the former may play a major role in the mode of addition and in the reaction outcome, as demonstrated by the production of mixtures of cis/trans aziridines 43/44 [29] (Scheme 12).

Scheme 12. Generation of $2 H$-azirines 42 by Grignard reagents and nucleophilic addition.

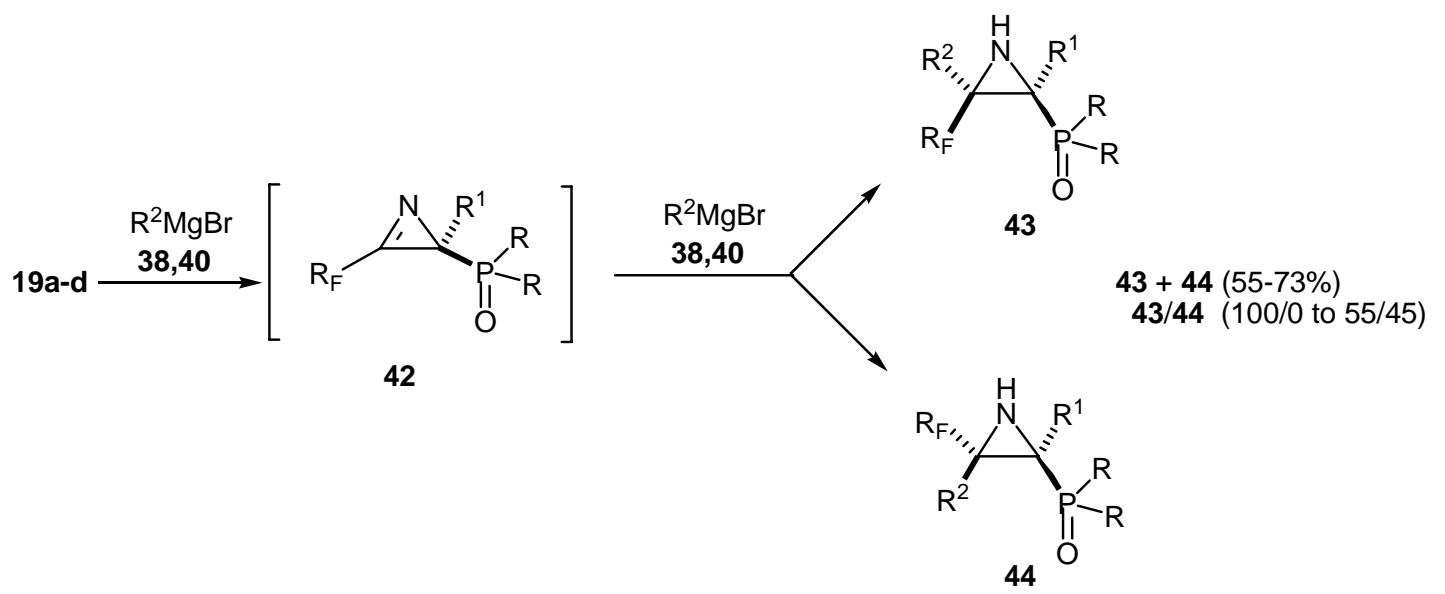

Carboxylic acids [26], $N$-protected aminoacids and peptide residues [34] also add to the carbon nitrogen double bond of phosphinyl- and phosphonyl- $2 H$-azirines. The concomitant ring opening leads to ketamides 48 (Scheme 13). 
Scheme 13. Ketamides 48 from $2 H$-azirines 23 and 29.<smiles>[R]C1NC1[PH]([R])([18OH])O[13CH3]</smiles><smiles>[R]C(=O)O</smiles>

$$
[
$$<smiles>[R]C(=O)OC1([R])NC1P([R])([R])=O</smiles>

46

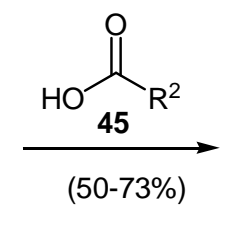<smiles>[R]C(=O)N[C@H](C([R])=O)[R]([R])([R])=O</smiles>

48<smiles>C1CCCCC1</smiles><smiles>[R]C1OC([R])(OC)NC1P([R])(=O)CC</smiles>

47

Due to their ambident character, phosphinyl- and phosphonyl- $2 H$-azirines also react as nucleophiles with carboxylic acid derivatives, such as acid chlorides, producing exclusively trans-aziridines $\mathbf{5 0}$ [35]. The scope of the reaction is not limited to simple chlorides since other functionalized acyl chlorides will react similarly in good overall yields.

Scheme 14. Reactions of acyl chlorides with phosphinyl- and phosphonyl-2H-azirines.<smiles>[R]C1=NC1P([R])([R])=O</smiles>

23 a,b; 29

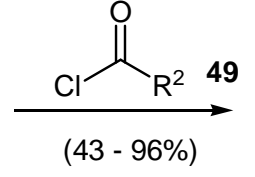

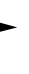

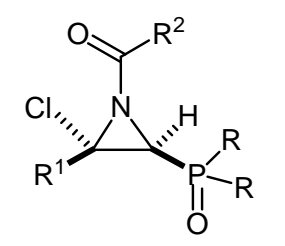

$50 \mathrm{R}=\mathrm{OEt} ; \mathrm{Ph}$

$\mathrm{R}^{1}=\mathrm{Me} ; \mathrm{Et} ; \mathrm{Ph}$

$\mathrm{R}^{2}=\mathrm{Me} ; \mathrm{Ph} ; \mathrm{CH}=\mathrm{CH}_{2}$;

$\left(\mathrm{CH}_{2}\right)_{4} \mathrm{CH}=\mathrm{CH}_{2}$

\subsection{Cycloadditions}

Simple alkyl- and aryl- $2 \mathrm{H}$-azirines, although being more reactive than acyclic imines, participate in Diels-Alder reactions only with highly reactive dienes, such as cyclopentadienones and 1,3-diphenylisobenzofuran in refluxing toluene [36], or with acyclic dienes and cyclopentadiene under Lewis acid catalysis [37,38]. 2H-Azirines with an alkoxy-, aryl-, amino-carbonyl [8,39] or heteroaromatic [40] substituent on the $\mathrm{C}=\mathrm{N}$ bond are particularly good dienophiles in Diels-Alder reactions with a great variety of dienes, as a consequence of the conjugated effect of ring strain and extra activation by the electron-withdrawing group.

Similarly enantiomerically enriched $2 \mathrm{H}$-azirine-3-phosphonates $\mathbf{5 1}$ when stirred with 100 equiv of 2,3-dimethylbutadiene or trans-piperylene for 2-4 days at room temperature or with Danishefsky's diene for 8 hours, afforded bicyclic aziridines $\mathbf{5 3}$ as single stereoisomers in good yields [23] (Scheme 15). 
Scheme 15. Cycloaddition reactions of $2 H$-azirine 51.

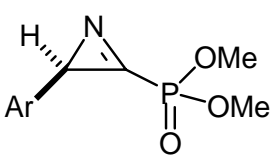

51

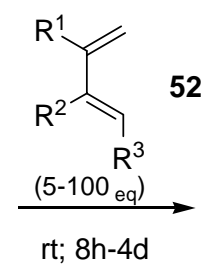

52

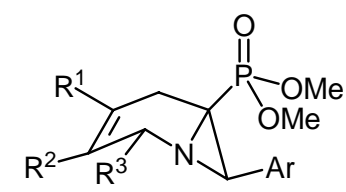

53a $\mathrm{R}^{1}=\mathrm{R}^{2}=\mathrm{Me} ; \mathrm{R}^{3}=\mathrm{H} ; \mathrm{Ar}=\mathrm{Ph}-\mathrm{OMe}-4$

b $\mathrm{R}^{1}=\mathrm{R}^{2}=\mathrm{Me} ; \mathrm{R}^{3}=\mathrm{H} ; \mathrm{Ar}=\mathrm{Ph}$

c $\mathrm{R}^{1}=\mathrm{R}^{2}=\mathrm{H} ; \mathrm{R}^{3}=\mathrm{Me} ; \mathrm{Ar}=\mathrm{Ph}-\mathrm{OMe}-4 \quad(89 \%)$

d $\mathrm{R}^{1}=\mathrm{OTMS} ; \mathrm{R}^{2}=\mathrm{H} ; \mathrm{R}^{3}=\mathrm{OMe} ; \mathrm{Ar}=\mathrm{Ph} \quad(97 \%)$

The stereochemistry of cycloadducts $\mathbf{5 3}$ was consistent with exclusive addition of the diene to the less hindered face of the azirine 51. The longer reaction times, when compared with $2 \mathrm{H}$-azirine-3carboxylates, may suggest that $2 \mathrm{H}$-azirine-3-phosphonates are less reactive than carboxylates.

Recently an azirine bearing both ethoxycarbonyl and phosphonate groups, was generated in situ and intercepted with a number of nucleophilic dienes [41]. With open chain dienes bicyclic functionalized six-membered ring fused aziridines were produced; although cyclic dienes afforded tryciclic structures. The presence of a trimethylsilyloxy group at the conjugated system, induced hydrolysis of cycloadduct 56f and 56c to 57 and 58 respectively (Scheme 16).

Scheme 16. Cycloaddition reactions of $2 H$-azirine 55 with nucleophilic dienes.

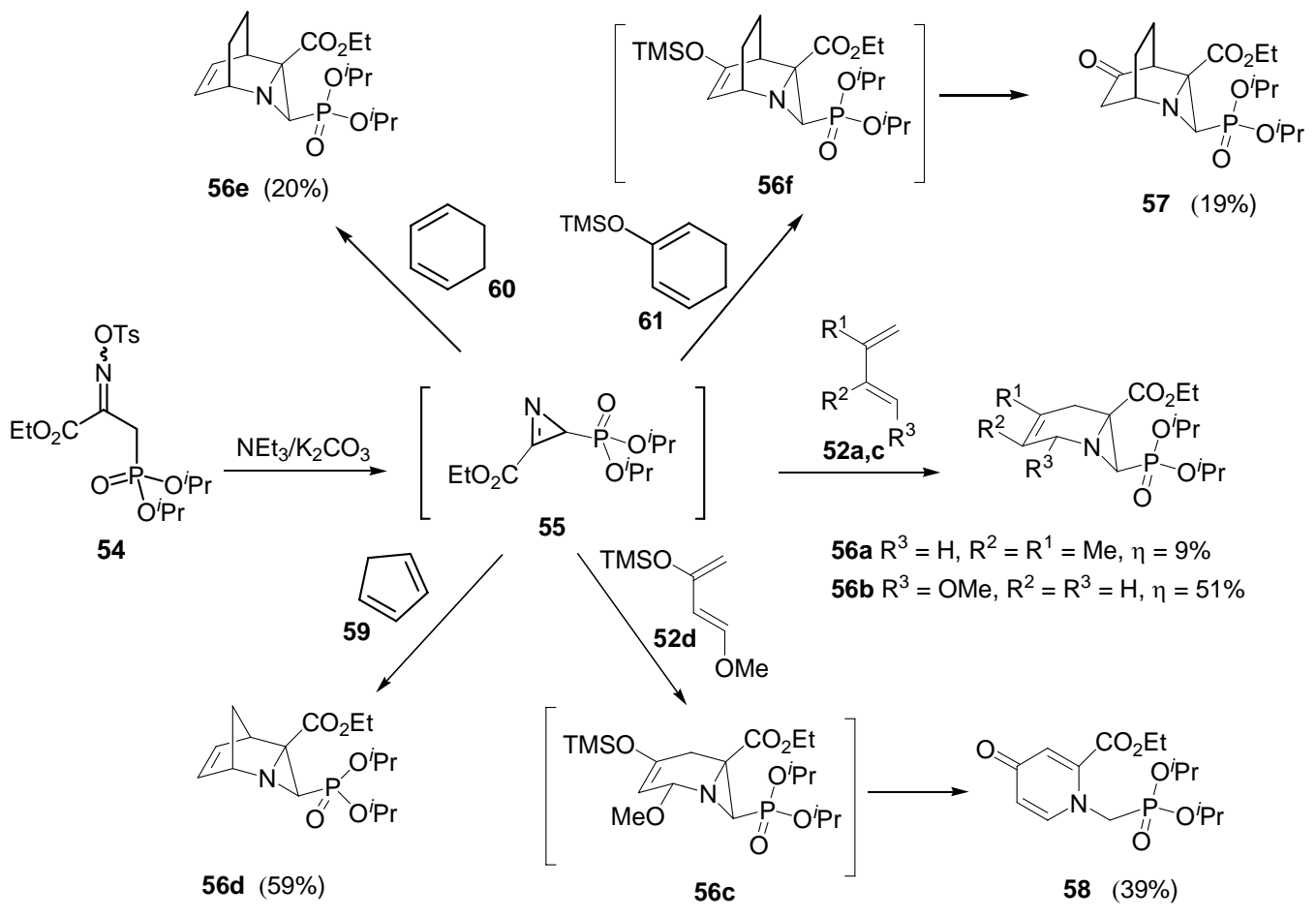

The products were isolated as single isomers, presumed to be formed by endo selective processes, as clearly indicated by the low field resonance of $\mathrm{H}-3$ in the tricyclic structure 56d, attributed to the anisotropy of the backside double bond over H-3, due to constrain of the tricyclic structure [42]. To the poor stability of azirine $\mathbf{5 5}$ was ascribed the low to moderate yields of cycloadducts (Scheme 16). 


\section{Nitroso- and Azo-alkenes}

Nitrosoalkenes and azoalkenes, used either as Michael-type acceptors in conjugate 1,4-additions, or as heterodienes in cycloaddition reactions with a range of nucleophiles, alkenes and heterocycles, have proved to be invaluable tools for the synthetic organic chemists.

\subsection{Synthesis or generation}

Electron-deficient nitrosoalkenes are, generally, very unstable species and for this reason, they are usually generated and intercepted in situ. Depending on the substituents, azoalkenes are sometimes stable enough to be isolated. Anyway, being isolated or generated "in situ", the most common, general and broad scope method for the obtention of nitroso- and azo-alkenes is the base induced 1,4-dehydro elimination from oximes and hydrazones bearing a suitable halogen or ester leaving group at the $\alpha$-position [1,2,4,7,10,11] (Scheme 17).

Scheme 17. General method for the obtention of nitroso- and azo-alkenes.
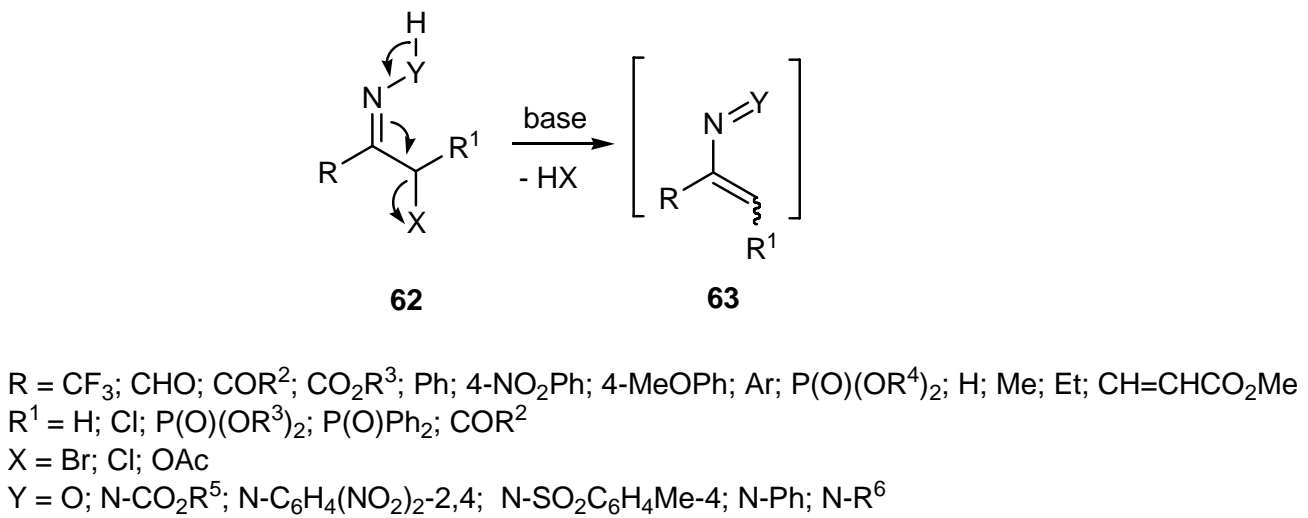

\subsection{Reactions with nucleophiles}

Although in reactions involving nitroso- and azo-alkenes generated and intercepted in situ, the distinction between nucleophilic substitution of the original $\alpha$-halogenated oxime or hydrazone and 1,4-conjugate (or Michael type) addition, is sometimes an intricate decision, the following reactions are thought to proceed via this latter process.

The primary literature reference to azoalkenes bearing phosphorus substituents [43] reported their use at the synthesis of 1-aminopyrroles substituted with a phosphine oxide or phosphonate group in the 3-position.

Achiral and chiral phosphinyl- and phosphonyl-1,2-diaza-1,3-butadienes obtained from hydrazonoalkyl-phosphine oxides and -phosphonates, were reported to add ammonia, aminoesters and aminoalcohols giving functionalized $a$-amino-phosphine oxides and -phosphonates [44,45] (Scheme 18). Very low diastereoselection with optically active amines was encountered - the adducts were isolated as nonseparable diastereoisomeric mixtures. Better diastereoselection was found when the bulky (S)-tert-leucinol substituent was used. 
Scheme 18. Nucleophilic addition of ammonia, aminoesters and aminoalcohols to azoalkene 64.

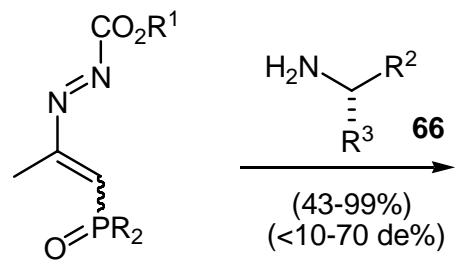

64

$\mathrm{NH}_{3}$

$\downarrow$<smiles>[R2][R](=O)NN=C(C)[C@@H](N)[R2](=O)[O-]</smiles>

$65 \mathrm{R}^{1}=\mathrm{Et} ; \mathrm{R}=\mathrm{Ph}(68 \%)$<smiles>[R]P[C@H](NC([R])[R2])/C(C)=N\NC([R])=O</smiles>

$67 \mathrm{R}=\mathrm{OEt}$; $\mathrm{Ph}$;

$\mathrm{R}^{1}=\mathrm{Et} ;(-)-M e n t$

$\mathrm{R}^{2}=\mathrm{Me} ; \mathrm{CH}_{2} \mathrm{OH} ; \mathrm{CHMeOH}$

$\mathrm{R}^{3}=\mathrm{H} ;{ }^{t} \mathrm{Bu} ; \mathrm{Ph}$

The diastereoselective addition of optically active amino esters gave slightly improved results when an optically active group was introduced at position 3 of the azoalkene. Thus the azovinylphosphonate 68 produced hydrazono derivatives $\mathbf{7 0}$ in good yields but moderate diastereoselectivity [46] (Scheme 19).

Scheme 19. Addition of amino esters to optically active azoalkene 68.<smiles>[R]C(N)CCC</smiles>

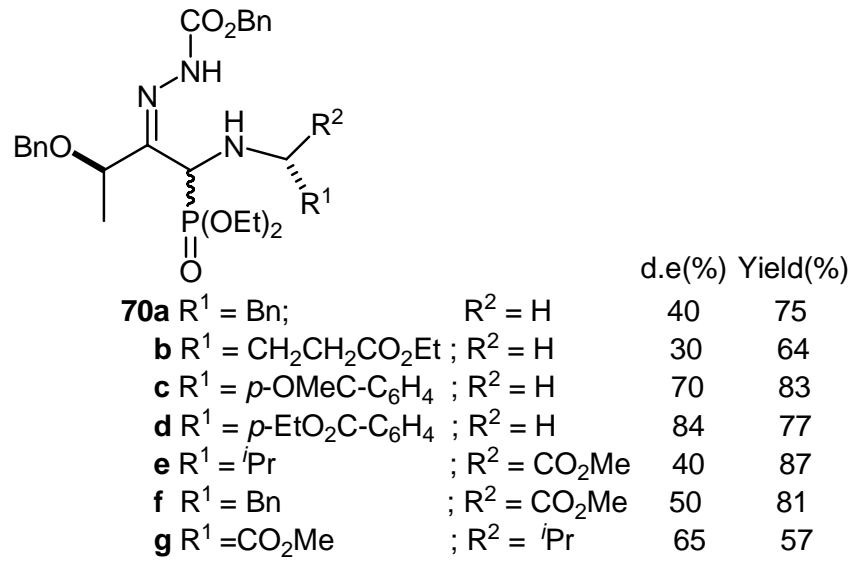

Amino- and alkoxy-carbonyl 1,2-diaza-1,3-dienes underwent 1,4-addtion with sulfur nucleophiles such as 1,2-aminothiols [47] (Scheme 20), thiourea [48] (Scheme 21) and 3-mercapto-2-ketones [49] (Scheme 22) producing either functionalized hydrazones or ensuing cyclised heterocycles. 
Scheme 20. 1,4-Addtion of 1,2-aminothiols 72 to nitrosoalkenes 71.<smiles>[R2][R](=O)/C=C(/C)N=NC(=O)O</smiles>

71

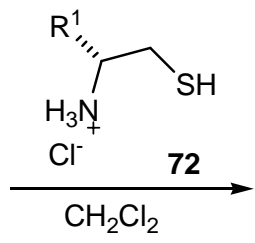

$\mathrm{R}^{1}$ $\mathrm{Cl}^{-} \mathrm{NH}_{3}$<smiles>[R2][C@H]([NH3+])CSC([R2](=O)OCC)/C(C)=N/NC(=O)OCC</smiles>

73<smiles>[R20]C1=C(C)NC([R2])CS1</smiles>

$$
\begin{aligned}
& \text { 74a } \mathrm{R}^{1}=\mathrm{H} \text {; } \\
& \text { b } \mathrm{R}^{1}=\mathrm{H} ; \quad \mathrm{R}=\mathrm{OEt}(90 \%) \\
& \text { c } \mathrm{R}^{1}=\mathrm{CO}_{2} \mathrm{Et} ; \mathrm{R}=\mathrm{Ph} \quad(83 \%) \\
& \text { d } \mathrm{R}^{1}=\mathrm{CO}_{2} \mathrm{Et} ; \mathrm{R}=\text { OEt (89\%) }
\end{aligned}
$$

Similarly, hydrazones $\mathbf{7 8 a}, \mathbf{b}$ arised from the 1,4-addition of oxygen nucleophiles to 1,2-diaza-1,3dienes [48] (Scheme 21).

Scheme 21. Addition of thiourea and methanol to 1,2-diaza-1,3-butadienes 75 .<smiles>[R]C(=O)C(=C([R])N=NC(N)=O)P(=O)(O)P</smiles>

75<smiles>NC(N)=S</smiles>

76

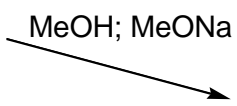<smiles>[R]C(=NNC(N)=O)C1(P(=O)(O)c2ccccc2)SC(=N)NC1=O</smiles>

77a $\mathrm{R}^{1}=\mathrm{OMe} ; \mathrm{R}^{2}=\mathrm{Me} ; \mathrm{R}^{3}=\mathrm{Me} \quad(61 \%)$

b $\mathrm{R}^{1}=\mathrm{OMe} ; \mathrm{R}^{2}=\mathrm{Et} ; \mathrm{R}^{3}=\mathrm{Et} \quad(60 \%)$

c $\mathrm{R}^{1}=\mathrm{OMe} ; \mathrm{R}^{2}=\mathrm{Me} ; \mathrm{R}^{3}=\mathrm{Et} \quad(63 \%)$<smiles>[R]C(=O)C(OC)(C([R])=NNC(N)=O)P(=O)(O)P</smiles>

78a $\mathrm{R}=\mathrm{OEt} ; \mathrm{R}^{1}=\mathrm{Me} ; \quad$ (65\%)

b $\mathrm{R}=\mathrm{OEt} ; \mathrm{R}^{1}=\mathrm{Et} ; \quad(78 \%)$

Scheme 22. Addition of 3-mercapto-2-ketones 80 to azoalkenes $\mathbf{7 9 .}$<smiles>[R]C(=O)N=N/C([R])=C\[PH]([R])([R])[O-]</smiles>

79

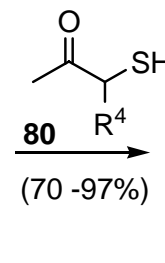

$\mathrm{R}^{1}=\mathrm{Me}, \mathrm{Et} ; \mathrm{R}^{2}=\mathrm{Ph}, \mathrm{OEt} ; \mathrm{R}^{3}=\mathrm{OEt} ; \mathrm{NH}_{2}$

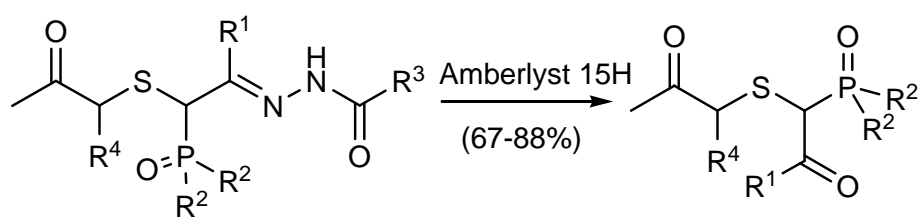

82

Under solvent free or solid-phase conditions, a Michael type addition of 1,2-diamines to phosphinyl- and phosphonyl-azoalkenes was observed, furnishing substituted hydrazones which subsequently were cyclised into pyridazines [50] (Scheme 23). 
Scheme 23. Addition of 1,2-diamines to phosphinyl- and phosphonyl-azoalkenes 83.<smiles>[R]P([R])(=O)C=C(C)N=NC(=O)OCC</smiles>

The nitrogen heteroaromatic $\mathrm{N}$-methylimidazole was reported to promote dehydrohalogenation of hydrazone $\mathbf{8 7}$ and to add regioselectively to the azo-alkene 89, conducting to functionalized $\alpha$-hydrazonophosphonate 91 [51] (Scheme 24).

Scheme 24. $N$-methylimidazole generation of azoalkene 89 and nucleophilic addition.

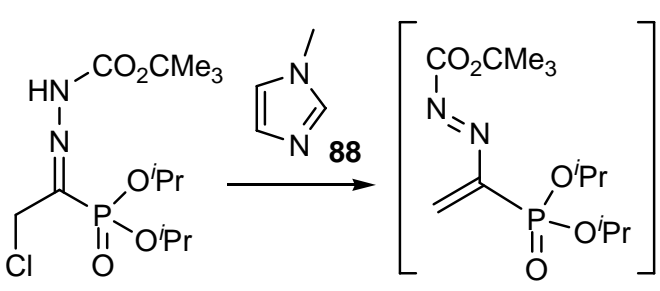

87

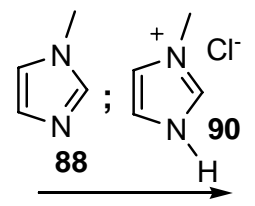<smiles></smiles>

$91(49 \%)$

Several examples of nucleophilic conjugate addition to nitrosoalkenes are reported in the literature [4,10,52-54], whereas reports of related reactions of phosphinyl- and phosphonyl-nitrosoalkenes are scarcely described. Nitrososalkenes 92, generated "in situ" from the corresponding $\alpha$-bromooxime, were reported to act as Michael acceptors towards ammonia, amines and optically active amino esters, affording $\alpha$-amino phosphine oxides and $\alpha$-amino phosphonates [55] (Scheme 25). The reactions, although being regioselective, lacked stereoselectivity with optically active compounds.

Scheme 25. Nitrosoalkenes 92 as Michael acceptors.<smiles>[R2]N([R])C([R]#N)/C(C)=N/O</smiles>

94

$\mathrm{R}=\mathrm{OEt} ; \mathrm{Ph}$

$\mathrm{R}^{3}=\mathrm{H}$; Ph; Et; 2-propynyl;

allyl, 4-MeOPh

$\mathrm{R}^{4}=\mathrm{H} ; \mathrm{Et}$

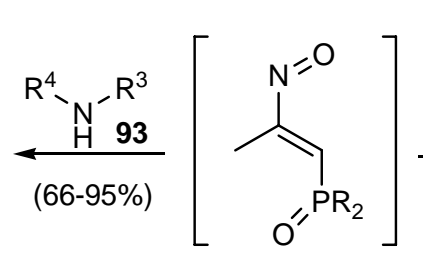

92

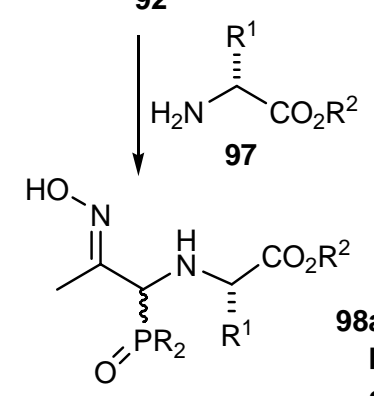

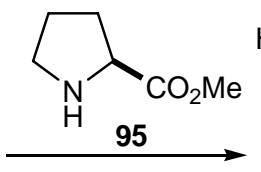<smiles>CC(=O)C1CCCN1[C@@H](C(C)=NO)[PH](=O)O</smiles>

96a $\mathrm{R}=\mathrm{Ph} \quad(87 \%)$

b $\mathrm{R}=\mathrm{OEt}(79 \%)$

$\begin{aligned} \text { 8a } \mathrm{R} & =\mathrm{Ph} ; \mathrm{R}^{1}={ }^{i} \mathrm{Pr} ; \mathrm{R}^{2}=\mathrm{Et}(90 \%) \\ \text { b } \mathrm{R} & =\mathrm{OEt} ; \mathrm{R}^{1}={ }^{i} \mathrm{Pr} ; \mathrm{R}^{2}=\mathrm{Et}(82 \%)\end{aligned}$

c $\mathrm{R}=\mathrm{Ph} ; \mathrm{R}^{1}=\mathrm{Bn} ; \mathrm{R}^{2}=\mathrm{Et}(83 \%)$ d $\mathrm{R}=\mathrm{OEt} ; \mathrm{R}^{1}=\mathrm{Bn} ; \mathrm{R}^{2}=\mathrm{Et} \quad(80 \%)$ 
There are various works reporting reactions of conjugated nitrosoalkenes with enamines [52,56-60] affording 1,2-oxazines in good to excellent yields via postulated Diels-Alder reactions with inverse electron demand. A more recent work [61] using density functional theory (DFT) studies, showed a polar character of the Diels-Alder reaction of nitrosoalkenes with enamines, being the two $\sigma$ bonds formed in these polar cycloaddition reactions in a highly asynchronous concerted process. On the other hand reactions of azoalkenes with enamines are solvent and structure - of enamine and azoalkene dependent [1,62-69], proceeding either via [4+2] cycloaddition or conjugate addition.

In this context, Palacios and co-workers [70] found that the reactions of nitrosoalkenes, bearing a phosphinyl or phosphonyl substituent at the terminal carbon, with enamines $\mathbf{9 9}$ did not proceed by [4+2] cycloaddition reactions producing the expected 1,2-oxazines, but $N$-hydroxypyrroles were instead isolated, presumably by a mechanism involving an initial conjugate addition of the enamine followed by a formal [3+2] dipolar cycloaddition (Scheme 26).

Scheme 26. Reaction of nitrosoalkenes 92 with enamines 99.<smiles>[R2]C1C(P=O)C(C)=NOC1([R])N1CCCC1</smiles>

100

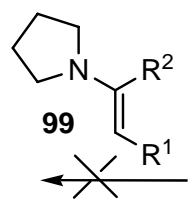

[<smiles>[R6][R20](=O)/C=C(/C)N=O</smiles>

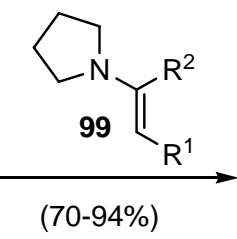<smiles>[14CH3]</smiles><smiles>[R]C(C([R2])C(C)/C(C)=N/OC)=[N+]1CCCC1</smiles>
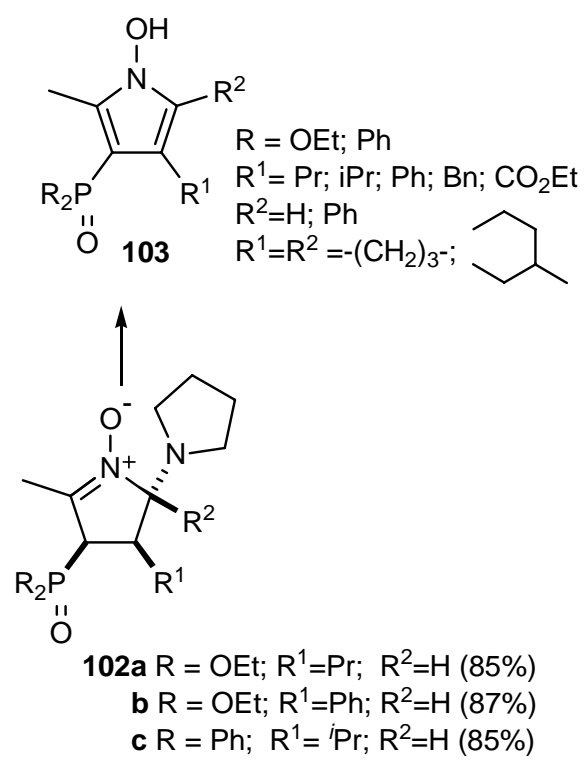

\subsection{Cycloadditions}

Cycloaddition reactions of nitroso- and azo-alkenes with electron rich carbon-carbon double bonds and heterocycles are important and powerful synthetic tools, as demonstrated by the enormous impetus of the chemistry of these compounds over the last decades.

Azoalkenes with a phosphinyl or phosphonyl substituent at the 4-position were generated by triethylamine induced dehydrohalogenation of chlorohydrazones [71]. Its interception with acyclicstyrene and cyclic - cyclopentadiene and norbornadiene alkenes and di-hydrofuran gave regio- and stereo-selectivelly endo cycloadducts, except in the case of the strained norbornadiene, which produced an exo cycloadduct (Scheme 27). 
Scheme 27. Cycloaddition reactions of azoalkenes 64 .

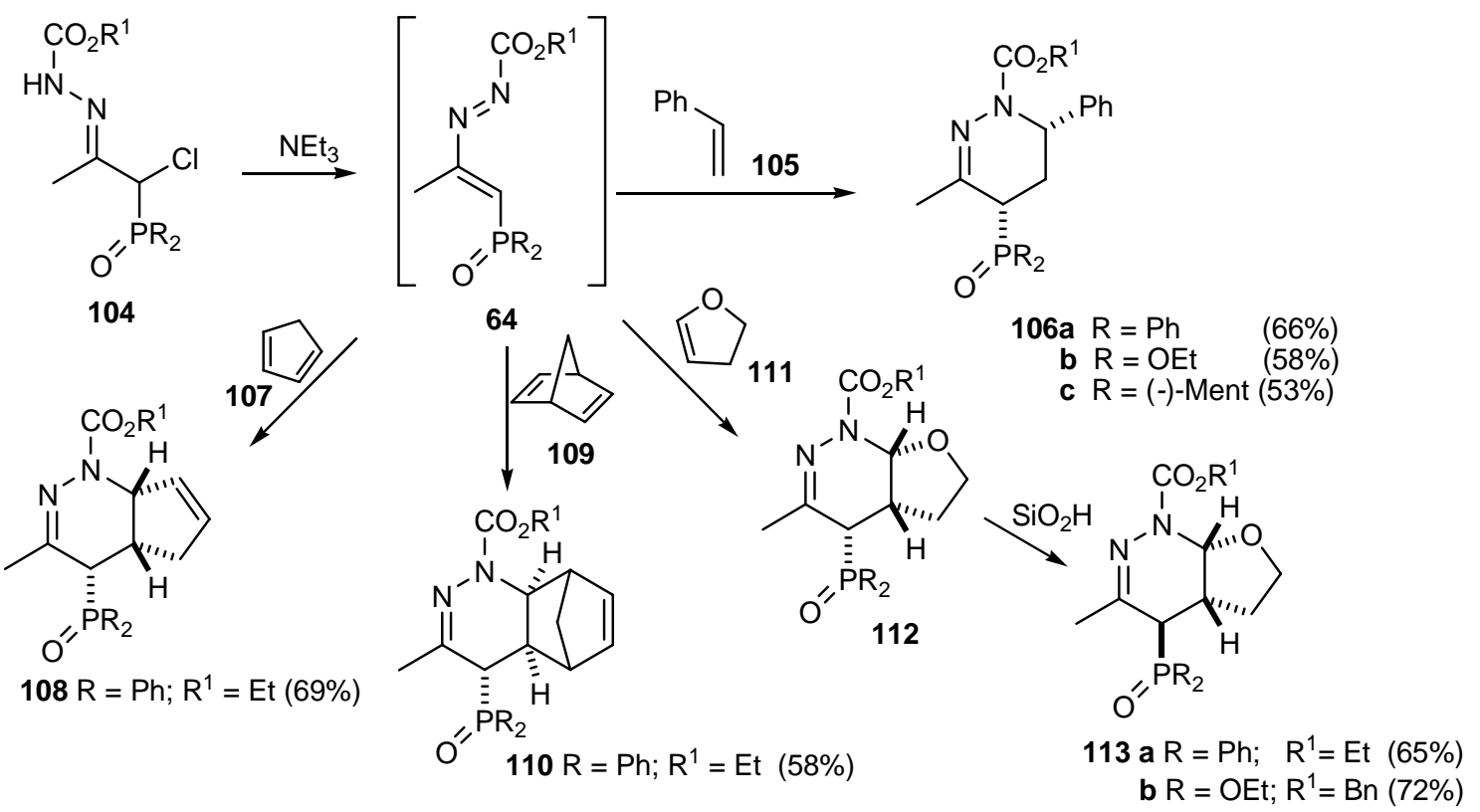

Attempts to bring about some degree of diastereoselectivity to the reaction, induced by the use of an optically active (-)-menthyl ester, were unsuccessful, since a diasteroisomeric ratio of 1:1 was found.

Cycloadducts were also obtained in regioselective fashion in reactions of azoalkenes bearing a phosphonate substituent at the 3-position with electron rich olefins [51] (Scheme 28).

Scheme 28. Cycloaddition reactions of azoalkenes 89 and 115 with electron rich olefins.<smiles>[X]CC(=NNC(C)=O)P([R])(=O)[O-]</smiles>
$114 \mathrm{X}=\mathrm{Br} ; \mathrm{R}=\mathrm{Et}$<smiles>[R][R]([H])(=O)C(=C)/N=N/C(C)=O</smiles>

89,115

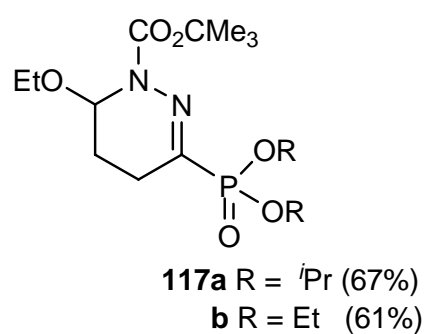<smiles>CCCOP(=O)(OCCC)C1=NN(C(C)=O)C(C)(c2ccccc2)CC1</smiles>

$119(22 \%)$

Reactions with electron rich heterocycles such furan and dihydrofuran gave rise to the formation of the corresponding cycloadducts. With pyrrole and indole open chain hydrazones were isolated (Table 2), assumed to be the result of rearomatization of the primarily formed cycloadducts [72]. The yields were, in general, lower than those obtained in similar reactions with azoalkenes bearing the same alkoxycarbonylazo substituent, but having an ethoxycarbonyl group at the 3-position [73], pointing out that eventually the ethoxycarbonyl group may play a more effective role than the phosphonate moiety. 
Table 2. Reactions of azoalkene $\mathbf{8 9}$ with electron-rich heterocycles.

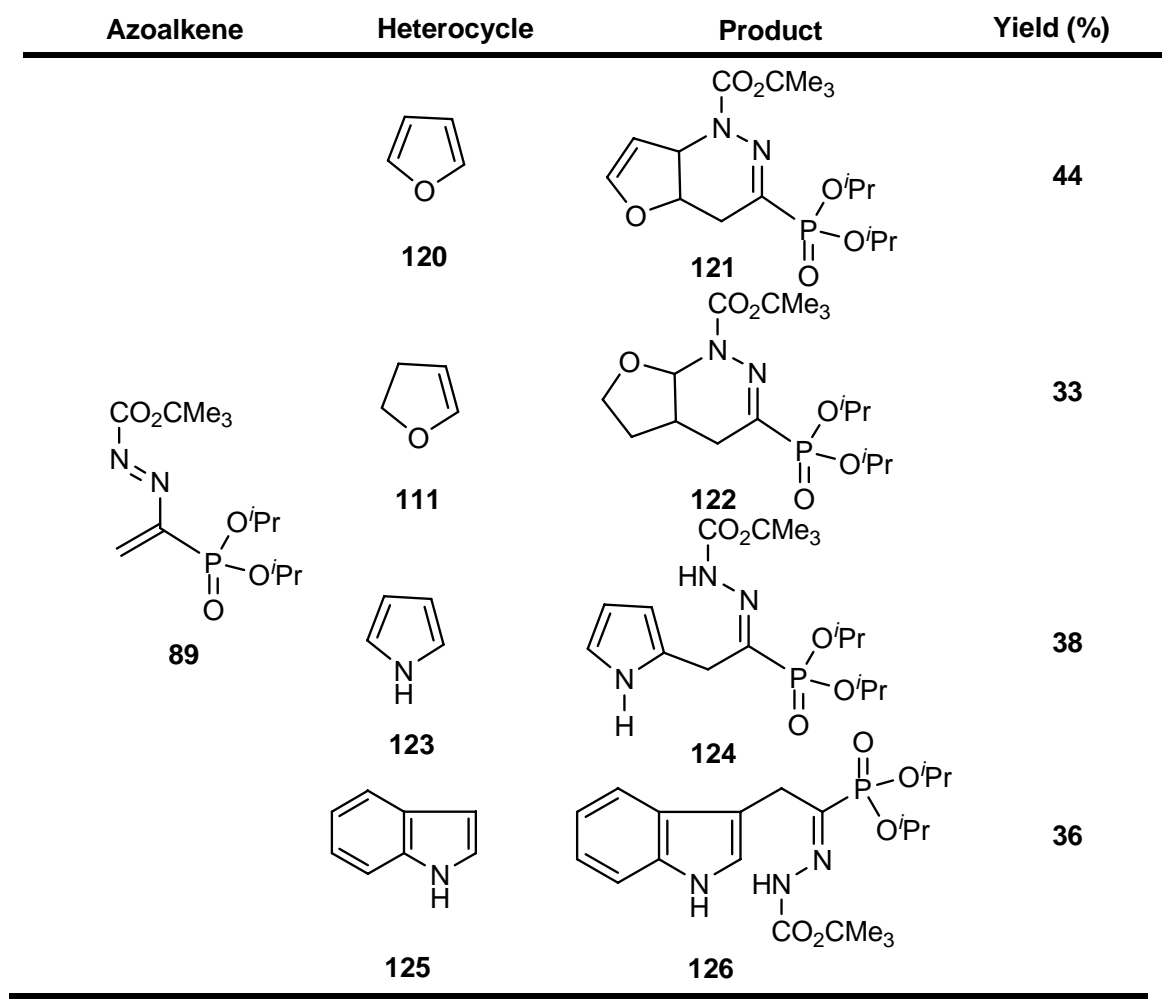

Nitrosovinylphosphonates generated from the corresponding chlorooximes were intercepted by electron-rich alkenes and heterocycles [74]. The yields, although not optimised, were fair and the reactions were found to be completely regioselective: no other isomers were detected or isolated from the reaction medium (Scheme 29).

Scheme 29. Cycloaddition reactions of nitrosovinylphosphonates $\mathbf{1 2 8}$.

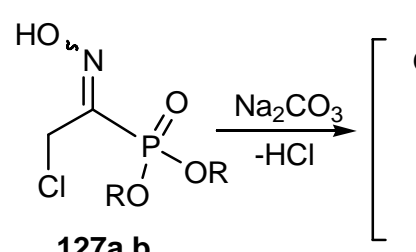

$127 a, b$

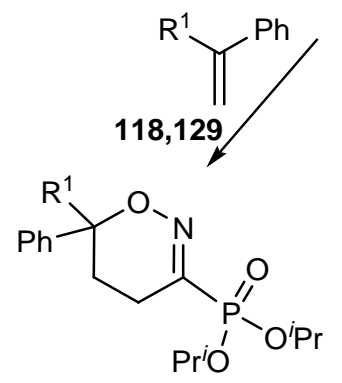

130a $R^{1}=H$ vestigial b $\mathrm{R}^{1}=\mathrm{Me} \quad 18 \%$<smiles>c1ccc2[nH]ccc2c1</smiles><smiles>CCCOP(=O)(OCCC)C(Cc1c[nH]c2ccccc12)=NO</smiles>

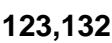<smiles>[Z17]n1cccc1C/C(=N/O)P(=O)(O[Ga])OCCC</smiles>

133a $R^{1}=H \quad(42 \%)$ b $\mathrm{R}^{1}=\mathrm{Me}(46 \%)$

131a $\mathrm{R}=\mathrm{OEt} \quad 64 \%$

b $\mathrm{R}=\mathrm{O}^{\mathrm{i}} \mathrm{Pr} 72 \%$ 


\section{Concluding Remarks}

Synthetic applications of $2 \mathrm{H}$-azirines, nitroso- and azo-alkenes bearing phosphinyl or phosphonyl substituents, emphasised towards the synthesis of $\alpha$ - and $\beta$-amino-phosphonates and -phosphine oxides have been addressed in this review. Established methods of aziridine ring opening [17,75] and reductive transformations at the $\mathrm{C}=\mathrm{N}$ bond [76-78] will further broaden the scope and importance of these strategies that surely will be further developed and attract the attention and interest of synthetic chemists.

\section{Acknowledgements}

Special thanks are due to T. L. Gilchrist for helpful suggestions and discussions.

\section{References and Notes}

1. Attanasi, O.A.; De Crescentini, L.; Favi, G.; Filippone, P.; Mantellini, F.; Perrulli, F.R.; Santeusanio, S. Cultivating the passion to build heterocycles from 1,2-diaza-1,3-dienes: The force of imagination. Eur. J. Org. Chem. 2009, 3109-3127.

2. Rai, K.M.L. Heterocycles via Oxime Cycloadditions. Top. Heterocycl. Chem. 2008, 13, 1-69.

3. Palacios, F.; Ochoa de Retana, A.M.; Marigorta, E.M.; de los Santos, J.M. Addition Reactions to the Imine Bond of $2 \mathrm{H}$-Azirines. Synthesis of Heterocyclic Compounds. In Recent Developments in Heterocyclic Chemistry; Pinho e Melo, T.M.V.D., Rocha-Gonsalves, A.M.A., Eds.; Research Signpost: Trivandrum, India, 2007; pp. 27-58.

4. Reissig, H.U.; Zimmer, R. 1-Nitrosoalkenes. In Science of Synthesis; Molander, G.A., Ed.; Thieme: Stuttgard, Germany, 2006; Vol. 33; pp. 371-389.

5. Pinho e Melo, T.M.V.D.; Rocha Gonsalves, A.M.A. Exploiting 2-halo-2H-Azirine chemistry. Curr. Org. Synth. 2004, 1, 275-292.

6. Palacios, F.; Ochoa de Retana, A.M.; Marigorta, E.M.; de los Santos, J.M. Preparation, properties and synthetic applications of $2 \mathrm{H}$-Azirines. A review. Org. Prep. Proced. Int. 2002, 34, 219-269.

7. Attanasi, O.A.; De Crescentini, L.; Filippone, P.; Mantelilini, F.; Santeusanio, S. 1,2-Diaza-1,3butadienes; just a nice class of compounds, or powerful tools in organic chemistry? Reviewing an experience. ARKIVOC 2002, 274-292.

8. Gilchrist, T.L. Activated 2H-Azirines as Dienophiles and Electrophiles. Aldrichim. Acta 2001, 34, 51-55.

9. Palacios, F.; Ochoa de Retana, A.M.; Marigorta, E.M.; de los Santos, J.M. 2H-Azirines as synthetic tools in organic chemistry. Eur. J. Org. Chem. 2001, 2401-2414.

10. Lyapkalo, I.M.; Ioffe, S.L. Conjugated Nitrosoalkenes. Russ. Chem. Rev. 1998, 67, 467-484.

11. Attanasi, O.A.; Filippone, P. Working twenty years on conjugated azo-alkenes (and environs) to find new entries in organic synthesis. Synlett 1997,1128-1140.

12. Ordóñez, M.; Rojas-Cabrera, H.; Cativiela, C. An overview of stereoselective synthesis of $\alpha$-aminophosphonic acids and derivatives. Tetrahedron 2009, 65, 17-49.

13. Palacios, F.; Alonso, C.; de los Santos, J.M. Synthesis of $\beta$-Aminophosphonates and -Phosphinates. Chem. Rev. 2005, 105, 899-931. 
14. Moonen, K.; Laureyn, I.; Stevens, C.V. Synthetic methods for azaheterocyclic phosphonates and their biological activity. Chem. Rev. 2004, 104, 6177-6215.

15. Kafarski, P.; Lejczak, B. The Biological Activity of Phosphono- and Phosphino-peptides. In Aminophosphinic and Aminophosphonic Acids. Chemistry and Biological Activity; Kukhar, V.P., Hudson, H.R., Eds.; John Wiley \& Sons Ltd: Chichester, UK, 2000; pp. 173-203, 407-442.

16. Kafarski, P; Lejczak, B. Biological activity of aminophosphonic acids. Phosphor. Sulfur Silicon 1991, 63, 193-215.

17. Singh, G.S.; D'hooghe, M.; De Kimpe, N. Synthesis and reactivity of $C$-heteroatom-substituted aziridines. Chem. Rev. 2007, 107, 2080-2135.

18. Christensen, B.G.; Beattie, T.R. Herstellung von Phosphonsäuren. Ger. Offen. 2,011,092, 1970; [Chem. Abstr. 1971, 74, 42491].

19. Russel, G.A.; Yao, C.F. Reactions of ethyl phosphites with $\beta$-nitrostyrenes. The role of nitrosoalkenes as intermediates. J. Org. Chem. 1992, 57, 6508-6513.

20. Alcaraz, G.; Wecker, U.; Baceiredo, A.; Dahan, F.; Bertrand, G. Synthesis of a $2 H$-Azirine by $[1+2]$ cycloaddition of a phosphinocarbene with a nitrile and its ring-expansion to a $1,2 \lambda^{5}$ Azaphosphete. Angew. Chem. Int. Ed. Engl. 1995, 34, 1246-1248.

21. Piquet, V.; Baceiredo, A.; Gornitzka, H.; Dahan, F.; Bertrand, G. The Stable (phosphino)(silyl)carbene as a useful building block: Synthesis and reactivity of 2-phosphorussubstituted 2H-Azirines. Chem. Eur. J. 1997, 3, 1757-1264.

22. Davis, F.A.; McCoull, W. Asymmetric synthesis of aziridine 2-phosphonates and azirinyl PHOSPHONATES from enantiopure sulfinimines. Tetrahedron Lett. 1999, 40, 249-252.

23. Davis, F.A.; Wu, Y.; Yan, H.; Prasad, K.R.; McCoull, W. 2H-Azirine 3-phosphonates: A new class of chiral iminodienophiles. asymmetric synthesis of quaternary piperidine phosphonates. Org. Lett. 2002, 4, 655-658.

24. Palacios, F.; Ochoa de Retana, A.M.; Gil, J.I.; Ezpeleta, J.M. Simple asymmetric synthesis of 2H-Azirines derived from phosphine oxides. J. Org. Chem. 2000, 65, 3213-3217.

25. Palacios, F.; Ochoa de Retana, A.M.; Gil, J.I. Easy and efficient synthesis of enantiomerically enriched $2 H$-azirines derived from phosphonates. Tetrahedron Lett. 2000, 41, 5363-5366.

26. Palacios, F.; Aparicio, D.; Ochoa de Retana, A.M.; de los Santos, J.M.; Gil, J.I.; Alonso, J.M. Asymmetric synthesis of $2 \mathrm{H}$-Azirines derived from phosphine oxides using solid-supported amines. Ring opening of azirines with carboxylic acids. J. Org. Chem. 2002, 67, 7283-7288.

27. Brel, V.K. New synthetic route to 2-(Diethylphosphono)-2H-Azirines. Synthesis 2002, 1829-1832.

28. Brel, V.K. Synthesis of 3-azido-4-(diethoxyphosphoryl)alka-1,3-dienes and their transformation to derivatives of $2 \mathrm{H}$-azirine. Synthesis 2007, 2674-2680.

29. Palacios, F.; Ochoa de Retana, A.M.; Alonso, J.M. Regioselective synthesis of fluoroalkylated $\beta$-aminophosphorus derivatives and aziridines from phosphorylated oximes and nucleophilic reagents. J. Org. Chem. 2006, 71, 6141-6148.

30. Palacios, F.; Ochoa de Retana, A.M.; Alonso, J.M. Reaction of $2 H$-Azirine phosphine oxide and phosphonates with nucleophiles. Stereoselective synthesis of functionalized aziridines and $\alpha$ - and $\beta$-aminophosphorus derivatives. J. Org. Chem. 2005, 70, 8895-8901. 
31. Carlson, R.M.; Lee, S.Y. Olefin synthesis via the stereospecific deamination of aziridines. Tetrahedron Lett. 1969, 10, 4001-4004.

32. Davis, F.A.; Liang, C.H.; Liu, H. Asymmetric synthesis of $\beta$-substituted $\alpha$-amino acids using $2 H$ azirine-2-carboxylate esters. Synthesis of 3,3-disubstituted aziridine-2-carboxylate esters. J. Org. Chem. 1997, 62, 3796-3797.

33. Davis, F.A.; Deng, J.; Zhang, Y.; Haltiwanger, R.C. Aziridine-mediated asymmetric synthesis of quaternary $\beta$-amino acids using $2 \mathrm{H}$-azirine 2-carboxylate esters. Tetrahedron 2002, 58, 7135-7143.

34. Palacios, F.; Ochoa de Retana, A.M.; Gil, J.I.; Alonso, J.M. Synthesis of optically active oxazoles and $N$-protected amino acids or peptides. Tetrahedron Asymmetry 2002, 13, 2541-2552.

35. Palacios, F.; Ochoa de Retana, A.M.; Gil, J.I.; Alonso, J.M. Regioselective synthesis of 4- and 5oxazole-phosphine oxides and -phosphonates from $2 \mathrm{H}$-azirines and acyl chlorides. Tetrahedron 2004, 60, 8937-8947.

36. Anderson D.J.; Hassner, A. Synthesis of heterocycles via cycloadditions to 1-azirines. Synthesis 1975, 483-495.

37. Ray, C.A.; Risberg, E.; Somfai, P. Lewis acid-catalyzed hetero Diels-Alder cycloadditions of 3alkyl, 3-phenyl and 3-carboxylated 2H-azirine. Tetrahedron Lett. 2001, 42, 9289-9291.

38. Ray, C.A.; Risberg, E.; Somfai, P. Diastereoselective Lewis acid-catalysed [4+2] cycloadditions of 3-alkyl-, 3-aryl- and 3-carboxyl-2H-azirines: A route to aziridine containing azabicyclo[4.1.0]heptanes and azatricyclo[2.2.1.0]nonanes. Tetrahedron 2002, 58, 5983-5987.

39. Gilchrist, T.L.; Mendonça, R. Synthesis and diels-alder reactions of $2 H$-azirine-3-carboxamides. ARKIVOC 2000, 769-778.

40. Alves, M.J.; Fortes, A.G.; Lemos, A.; Martins, C. Ethyl 3-(2-pyridyl)-2H-azirine-2-carboxylate: synthesis and reaction with dienes. Synthesis 2005, 555-558.

41. Alves, M.J.; Lemos, A.; Rodriguez-Borges, J.E.; García-Mera, X.; Fortes, A.G. Ethyl 2(diisopropoxyphosphoryl)-2H-azirine-3-carboxylate: Reactions with nucleophilic 1,3-dienes. Synthesis 2009, 3263-3266.

42. Alves, M.J.; Gilchrist, T.L. Methyl 2-aryl-2H-azirine-3-carboxylates as dienophiles. J. Chem. Soc. Perkin 1 1998, 299-303.

43. Palacios, F.; Aparicio, D.; de 1os Santos, J.M. An efficient strategy for the regioselective synthesis of 3-phosphorylated-1-aminopyrroles from $\beta$-hydrazono phosphine oxides and phosphonates. Tetrahedron 1999, 55, 13767-13778.

44. Palacios, F.; Aparicio, D.; López, Y.; de los Santos, J.M. Addition of amine derivatives to phosphorylated 1,2-diaza-1,3-butadienes. Synthesis of $\alpha$-aminophosphonates. Tetrahedron Lett. 2004, 45, 4345-4348.

45. Palacios, F.; Aparicio, D.; López, Y.; de los Santos, J.M.; Ignacio, R. An efficient synthesis of functionalized $\alpha$-amino-phosphine oxides and -phosphonates by addition of aminoalcohols to 4phosphorylated-1,2-diaza-1,3-butadienes. Arkivoc 2005, 153-161.

46. Palacios, F.; Aparicio, D.; López, Y.; de los Santos, J.M. Synthesis of functionalized a-aminophosphine oxides and -phosphonates by addition of amines and aminoesters to 4-phosphinyl- and 4-phosphonyl-1,2-diaza-1,3-butadienes. Tetrahedron 2005, 61, 2815-2830. 
47. Attanasi, O.A.; Filippone, P.; Lillini, S.; Mantellini, F.; Nicolini, S.; de los Santos, J.M.; Ignacio, R.; Aparicio, D.; Palacios, F. Reactions of 1,2-diaza-1,3-dienes with thiol derivatives: A versatile construction of nitrogen/sulfur heterocycles. Tetrahedron 2008, 64, 9264-9274.

48. Attanasi, O.A.; Baccolini, G.; Boga, C.; De Crescentini, L.; Favi, G.; Filippone, P.; Mantellini, F. Carbon-phosphorus bond formation and transformation in the reaction of 1,2-diaza-1,3-butadienes with alkyl phenylphosphonites. Tetrahedron 2008, 64, 6724-6732.

49. Attanasi, O.A.; Filippone, P.; Lillini, S.; Mantellini, F.; de los Santos, J.M.; Ignacio, R.; Palacios, F. Domino reaction for the construction of new 2-Oxo[1,2,4]triazolo[5,1-c]thiazines. Synlett 2009, 735-738.

50. Aparicio, D.; Attanasi, O.A.; Filippone, P.; Ignacio, R.; Lillini, S.; Mantellini, F.; Palacios, F.; de los Santos, J.M. Straightforward access to pyrazines, piperazinones, and quinoxalines by reactions of 1,2-diaza-1,3-butadienes with 1,2-diamines under solution, solvent-free, or solid-phase conditions. J. Org. Chem. 2006, 71, 5897-5905.

51. Lemos, A.; Lopes, M. Reactions of azovinylphosphonates with nucleophilic alkenes and heterocycles: Synthesis of tetrahydropyridazine-3-phosphonate and 2-substituted-1hydrazonoethylphosphonate derivatives. Phosphor. Sulfur Silicon 2008, 183, 2882-2890.

52. Gilchrist, T.L; Lingham, D.A.; Roberts, T.G. Ethyl 3-bromo-2-hydroxyiminopropanoate, a reagent for the preparation of ethyl esters of $\alpha$-amino acids. J. Chem. Soc. Chem. Commun. 1979, 1089-1090.

53. Gilchrist, T.L.; Stretch, W.; Chrystal, E.J.T. Reaction of azoles with ethyl bromopyruvate oxime: Alkylation by substitution and by elimination-addition. J. Chem. Soc. Perkin Trans. 1 1987, 2235-2239.

54. Zimmer, R.; Reissig, H.U. Efficient synthesis of trifluoromethyl-substituted 5,6-dihydro-4H-1,2oxazines by the hetero-diels-alder reaction of 1,1,1-trifluoro-2-nitroso-2-propene and electron-rich olefins. J. Org. Chem. 1992, 57, 339-347.

55. De los Santos, J.M.; Ignacio, R.; Aparicio, D.; Palacios, F. Michael addition of amine derivatives to conjugate phosphinyl and phosphonyl nitrosoalkenes. Preparation of $\alpha$-amino phosphine oxide and phosphonate derivatives. J. Org. Chem. 2007, 72, 5202-5206.

56. Henning, R.; Lerch, U.; Urbach, H. Synthesis of esters of lipophilic proline analogs by reduction of ethyl 5,6- dihydro-4H-1,2-oxazine-3-carboxylates. Synthesis 1989, 265-268.

57. Paulini, K.; Reissig, H.U.; Rademacher, P. On the reactivity of N,N-bis(trimethyl)silylated enamines: Model studies on hetero Diels-Alder reactions and other cycloadditions. J. Prakt. Chem. 1995, 337, 209-215.

58. Gallos, J.K.; Sarli, V.C.; Varvogli, A.C; Papadoyanni, C.Z.; Papaspyrou, S.D.; Argyropoulos, N.G. The hetero-Diels-Alder addition of ethyl 2-nitrosoacrylate to electron-rich alkenes as a route to unnatural $\alpha$-amino acids. Tetrahedron Lett. 2003, 44, 3905-3909.

59. Wabnitz, T.C.; Saaby, S.; Jorgensen, K.A. The first catalytic inverse-electron demand heteroDiels-Alder reaction of nitroso alkenes using pyrrolidine as an organocatalyst. Org. Biomol. Chem. 2004, 2, 828-834.

60. Gallos, J.K.; Sarli, V.C.; Massen, Z.S.; Varvogli, A.C.; Papadoyanni, C.Z; Papaspyrou, S.D.; Argyropoulos, N.G. A new strategy for the stereoselective synthesis of unnatural $a$-amino acids. Tetrahedron 2005, 61, 565-574. 
61. Domingo, L.R.; Picher, M.T.; Arroyo, P. Towards an understanding of the polar Diels-Alder reactions of nitrosoalkenes with enamines: A theoretical study. Eur. J. Org. Chem. 2006, 2570-2580.

62. Rossi, E.; Abbiati, G.; Attanasi, O.A.; Rizzato, S.; Santeusanio, S. Divergent and solvent dependent reactions of 4-ethoxycarbonyl-3-methyl-1-tert-butoxycarbonyl-1,2-diaza-1,3-diene with enamines. Tetrahedron 2007, 63, 11055-11065.

63. Attanasi, O.A.; Favi, G.; Filippone, P.; Forzato, C.; Giorgi, G.; Morganti, S.; Nitti, P.; Pitacco, G.; Rizzato, E.; Spinelli, S.; Valentin, E. On the reactivity of some 2-methyleneindolines with $\beta$ nitroenamines, $\alpha$-nitroalkenes, and 1,2-diaza-1,3-butadienes. Tetrahedron 2006, 62, 6420-6434.

64. South, M.S. Novel cyclization reactions of mono- and dichloroazodienes. A new synthesis of substituted pyridazines. J. Heterocycl. Chem. 1999, 36, 301-319.

65. South, M.S.; Jakuboski, T.L.; Westmeyer, M.D.; Dukesherer, D.R. Synthesis and reactions of haloazodienes. A new and general synthesis of substituted pyridazines. J. Org. Chem. 1996, 61, 8921-8934.

66. South, M.S.; Jakuboski, T.L.; Westmeyer, M.D.; Dukesherer, D.R. Novel cyclization reactions of dichloroazodienes. Tetrahedron Lett. 1996, 37, 1351-1354.

67. South, M.S.; Jakuboski, T.L. Synthesis and reactions of chloroazodienes. A new and general synthesis of pyridazines. Tetrahedron Lett. 1995, 36, 5703-5706.

68. Clarke, S.J.; Davies, D.E.; Gilchrist, T.L. Competing [4+2] and [3+2] cycloaddition in the reactions of nucleophilic olefins with ethyl 3-(toluene- $p$-sulphonylazo)but-2-enoate. J. Chem. Soc. Perkin Trans. 1 1983, 1803-1807.

69. Sommer, S. [3+2]-cycloadditionen von azoalkenen an enamine-“criss-cross"-cycloadditionen an azoalkene. Angew.Chem. 1979, 91, 756-757.

70. De los Santos, J.M.; Ignacio, R.; Aparicio, D.; Palacios, F.; Ezpeleta, J.M. Reactions of conjugate phosphinyl- and phosphonyl-nitroso alkenes with enamines. Preparation of $N$-hydroxypyrrole derivatives. J. Org. Chem. 2009, 74, 3444-3448.

71. Palacios, F.; Aparicio, D.; López, Y.; De los Santos, J.M.; Alonso, C. Cycloaddition reactions of phosphorylated 1,2-diaza-1,3-butadienes with olefins: Regioselective synthesis of pyridazine derivatives. Eur. J. Org. Chem. 2005, 1142-1147.

72. Gilchrist, T.L.; Lemos, A. Reaction of pyrroles with ethyl 2-nitroso- and 2-azo-propenoates, and with ethyl cyanoformate $N$-oxide: A comparison of the reaction pathways. J. Chem. Soc. Perkin Trans. 1 1993, 1391-1395.

73. Clarke, S.J.; Gilchrist, T.L.; Lemos, A.; Roberts, T.G. Reactions of azoalkenes derived from hydrazones of ethyl bromopyruvate with electron rich alkenes and heterocycles. Tetrahedron 1991, 47, 5615-5624.

74. Lemos, A.; Lopes, M. Reactions of nitrosovinylphosphonates with electron-rich alkenes and heterocycles. Phosphor. Sulfur Silicon 2007, 182, 2149-2155.

75. Hu, E.X. Nucleophilic ring opening of aziridines. Tetrahedron 2004, 60, 2701-2743.

76. Rogers, R.S.; Stern, M.K. An improved synthesis of the phosphonic acid analog of tryptophan. Synlett 1992, 708-708. 
77. Burk, M.J.; Martinez, J.P.; Feaster, J.E.; Cosford, N. Catalytic asymmetric reductive amination of ketones via highly enantioselective hydrogenation of the $\mathrm{C}=\mathrm{N}$ double bond. Tetrahedron 1994, 50, 4399-4428.

78. Demir, A.S.; Tanyeli, C.; Sesenoglu, O.; Demiç, S. A simple synthesis of 1-aminophosphonic acids from 1-hydroxyiminophosphonates with $\mathrm{NaBH}_{4}$ in the presence of transition metal compounds. Tetrahedron Lett. 1996, 37, 407-410.

Sample Availability: Not applicable.

(C) 2009 by the authors; licensee Molecular Diversity Preservation International, Basel, Switzerland. This article is an open-access article distributed under the terms and conditions of the Creative Commons Attribution license (http://creativecommons.org/licenses/by/3.0/). 